\title{
Study of the nitrided layer obtained by different nitriding methods
}

\author{
Elisangela Aparecida dos Santos de Almeida ${ }^{1}$, César Edil da Costa ${ }^{2}$, \\ Júlio César Giubilei Milan ${ }^{3}$
}

\author{
1,2,3 Mechanical Engineering Laboratory - PGCEM/UDESC, Centro de Ciências Tecnológicas - CCT/ Paulo Malchitzki \\ street, Campus Universitário Prof. Avelino Marcante - District: Zona Industrial Norte - CEP: 89225-100 - Joinville - SC \\ - Brazil. \\ e-mail: elisangela_s_almeida@yahoo.com.br \\ e-mail: cesar.edil@udesc.br; julio.milan@udesc.br
}

\begin{abstract}
In this study, plasma nitriding, gas nitriding and solid nitriding were performed in AISI H13, AISI P20 and N-8550 tool steels. The aim of the study was compare the acquired properties after the thermochemical treatments and evaluate the efficiency of the solid nitriding treatment. The samples were analyzed using a microhardness tester and a scanning electron microscope. The typical nitriding layers were observed - white layer and diffusion layer. The phases $\mathrm{Fe}_{4} \mathrm{~N}-\gamma^{\prime}$ and $\mathrm{Fe}_{2,3} \mathrm{~N}-\varepsilon$ were identified using an X-Ray diffractometer. The microhardness values of the nitrided layers obtained by the solid nitriding treatment were compatible with the other values of microhardness obtained by plasma and gas nitriding. The thickness of the nitrided layer obtained by the solid nitriding treatment was irregular.
\end{abstract}

Keywords: Solid nitriding. Tool steels. Nitriding Layers.

\section{INTRODUCTION}

Nitriding is a thermochemical treatment that consists in the introduction of nitrogen into metallic material.

Nitriding promotes higher superficial hardness, increases the wear resistance and fatigue resistance, and improves the corrosion resistance of the treated material $[\underline{1}, \underline{2}]$.

Gas nitriding is promoted by holding the metal at a suitable temperature, submitting the samples to a gas atmosphere that contains nitrogen, normally ammonia [3]]. Gas nitriding requires a specific oven with inlets and outlets of gas where that is possible to control the treatment atmosphere.

Ion/plasma nitriding uses a glow discharge to introduce nitrogen into the metallic material. For this process it is important that the samples are in a vacuum environment, so that the nitrogen ions can be accelerated and impinge the steel surface diffusing into it $[\underline{4}, \underline{5}]$.

Different layers are produced on the steel through the nitriding treatment: the diffusion layer with or without a compound layer (white layer) [5].

The white layer consists in a mixture of iron nitrides: $\mathrm{Fe}_{4} \mathrm{~N}-\gamma^{\prime}$ and/or $\mathrm{Fe}_{2,3} \mathrm{~N}-\varepsilon$. The diffusion layer is located bellow the white layer, and it is formed by the diffusion of nitrogen into the metal. The diffusion zone is a region characterized by some solid solution in the original core microstructure, with some hardening precipitation. Controlling plasma process parameters it is possible to produce a single layer of $\mathrm{Fe}_{4} \mathrm{~N}-\gamma^{\prime}$ or a single layer of $\mathrm{Fe}_{2,3} \mathrm{~N}-\varepsilon$, or avoid the formation of the compound layer [ $\left.\underline{5}-\underline{9}\right]$.

In nitriding treatments the surface cleaning of the specimen is very important, because adsorbed oxygen and contaminants on the surface of the sample form a barrier to the diffusion of nitrogen into the substrate $[\underline{10}-\underline{13}]$.

Comparing gas nitriding and plasma nitriding, Anichkina et al., [14], verified that the growth rate of the diffusion layer for the ion nitriding of a low alloy steel is greater than that obtained by gas nitriding. Plasma nitriding is faster than conventional gas nitriding due to the different mechanisms of nitrogen introduction into the metal [15].

Temperature can affect the hardness of the gas nitrided case AISI H11 [16]. The effect of varying pro- 
cess parameters as time and temperature is widely used $[\underline{2}, \underline{17}]$.

Plasma nitriding treatment promotes greater control of different treatment parameters and this enables a higher reproducibility of results and also allows the control of the microstructure of the nitrided layer [18].

Gas and plasma nitriding are well established and are extensively used techniques, but these techniques require the use of complicated apparatus [17]. Solid nitriding consists in promote the diffusion of nitrogen into the metallic material using a $\mathrm{Fe}_{4} \mathrm{KCN}$ granulated (Turbonit $\mathrm{k} 20^{\circledR}$ ), and the process needs only a muffle oven to promote the heating. Being a low-cost process, without using special equipments, that is important to evaluate its potential in comparison with more elaborated process as plasma and gas nitriding.

In this study solid nitriding treatment was compared with gas and plasma nitriding, the three different treatments were performed in different tool steels. In order to evaluate the results a microhardness tester and a scanning electron microscope were used. An X-ray diffractometer identified the phases formed in the three treatments.

\section{MATERIALS AND METHODS}

Materials - Commercial steels were applied because of its large application: AISI H13, AISI P20 and N-8550. Table 1 shows the composition of the steels.

In order to promote the solid nitriding, a granulated known as Turbonit $\mathrm{k}-20^{\circledR}$ was used. Turbonit k$20^{\circledR}$ stoichiometric formula is $\mathrm{Fe}_{4} \mathrm{KCN}$.

A muffle oven was used to promote the solid nitriding. Scan Electron Microscope (SEM), Microhardness tester and a Diffractometer were used to analyze the samples.

Table 1: Materials composition (weight \%).

\begin{tabular}{l|c|c|c|c|c|c|c|c|c|c}
\hline & $\mathbf{C}$ & $\mathbf{C r}$ & $\mathbf{M n}$ & $\mathbf{S i}$ & $\mathbf{M o}$ & $\mathbf{V}$ & $\mathbf{N i}$ & $\mathbf{P}$ & $\mathbf{W}$ & Al \\
\hline AISI H13 & 0,39 & 5,2 & 0,31 & 0,89 & 1,25 & 0,82 & 0,17 & 0,025 & 0,06 & 0,018 \\
\hline AISI P20 & 0,35 & 1,86 & 0,02 & 0,28 & 0,42 & 0,01 & 0,87 & 0,02 & $\ldots \ldots$ & $\ldots \ldots$ \\
\hline $\mathbf{N - 8 5 5 0}$ & 0,33 & 1,65 & 0,50 & 0,2 & 0,23 & $\ldots \ldots$ & 0,96 & $\ldots \ldots$ & $\ldots \ldots$ & 0,98 \\
\hline
\end{tabular}

Samples Preparation - The steels substrate samples (AISI H13, AISI P20 and N-8550) measuring Ø 1 inch x $15 \mathrm{~mm}$, were obtained from commercial bars. The N-8550 is provided quenched and tempered, the AISI H13 is provided annealed and the AISI P20 is provided quenched and tempered. Before the thermochemical treatments the samples were polished with abrasive particles up to $1 \mu \mathrm{m}$ and ultrasonically cleaned in order to remove particles and degrease the samples.

Nitriding Treatments - Three different nitriding treatments were applied to the steels: solid nitriding, gas nitriding and plasma/ion nitriding. The treatments temperature was $560{ }^{\circ} \mathrm{C}$.

The atmosphere applied for gas nitriding was $50 \% \mathrm{~N}_{2}, 50 \% \mathrm{NH}_{3}$, and a small amount of $\mathrm{CO}_{2}$; this treatment was performed during 10 hours. Plasma nitriding atmosphere was $20 \% \mathrm{~N}_{2}$ and $80 \% \mathrm{H}_{2}, 3$ hours treatment. The solid nitriding treatment was applied for 10 hours.

The solid nitriding uses a solid granulated which stoichiometric formula is $\mathrm{Fe}_{4} \mathrm{KCN}$. It is commercially known as Turbonit k-20 ${ }^{\circledR}$. The steel samples were surrounded by the granulated inside an aluminum made container and confined inside it, so that the gas generated is kept inside the container. The samples were placed in the container maintaining a distance of about $15 \mathrm{~mm}$ between them and between the edges of the container. A muffle oven is required to promote the heating for the nitriding process.

During the solid nitriding treatment, the heating of the granulated generates atomic nitrogen that can diffuse into the steel.

Microscopy and Microhardness - The nitriding layers were observed using SEM. It was possible to identify the white/compound zone and the diffusion zone and measure the thickness of the formed layers.

Microhardness results were obtained using a Vickers microhardness tester. The result was the average of three microhardness values. The load applied was $10 \mathrm{gf}\left(\mathrm{HV}_{0.01}\right)$.

X-ray Diffraction - The phases formed by the nitriding treatments were verified by X-ray diffraction. The X-ray diffractometer used a copper anode, monochromatic $\mathrm{Cu} \mathrm{Ka}$ radiation. The XRD patterns were obtained using step scanning of $0.02^{\circ}$, counting time of $0.6 \mathrm{~s}$, Current: $30 \mathrm{~mA}$ and ddp: $40 \mathrm{kV}$. The scanning angle $(2 \theta)$ comprises the range of $20-90^{\circ}$. 


\section{RESULTS AND DISCUSSION}

It is observed for the three treatments in the samples of AISI H13, the presence of compound layers (white layer) of different thicknesses, and also the diffusion layer for the plasma and solid nitrided samples.

All the treatments promoted the formation of the nitrided zones. All micrographs showed the compound zone formation. Although that was not possible to observe the diffusion zone in some cases, the compound layer is supported by the diffusion zone. It occurs because the coherent precipitates in the diffusion zone are not large enough to resolve [ $[$ ].

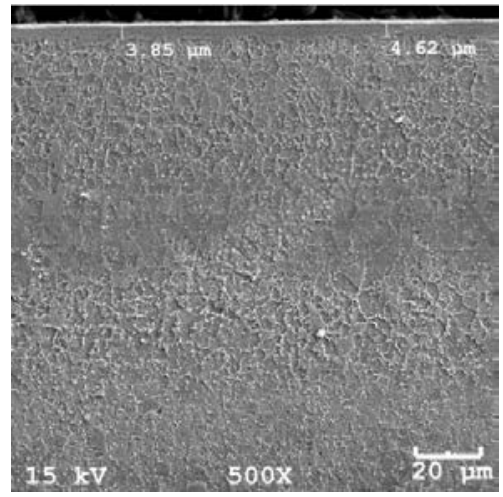

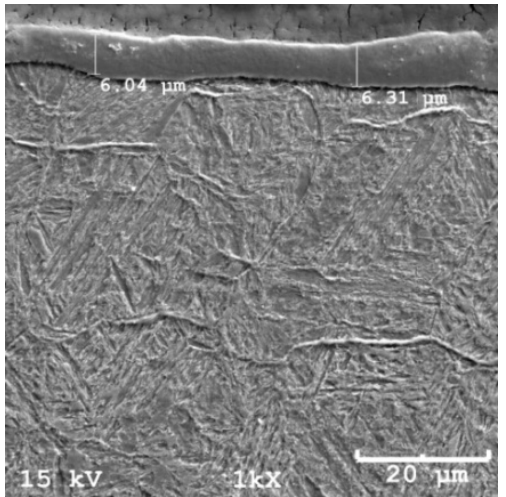

b

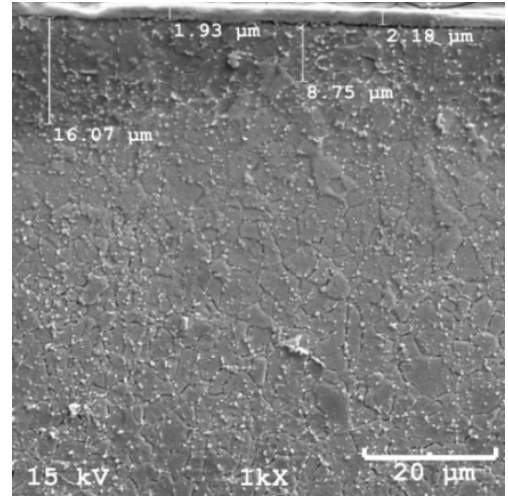

C

Figure 1: AISI H13 steel thermochemically treated a) plasma nitriding; b) gas nitriding; c) solid nitriding.

It can be seen in the micrographs of Figure 1, that the plasma nitriding provided the formation of a thick diffusion layer. It can be seen through the difference on the microstructure that the thickness of the diffusion layer is approximately $80 \mu \mathrm{m}$.

The diffusion layer in plasma nitriding is thicker than the diffusion layer obtained by other processes because it is a process with high control parameters, with different mechanisms of nitriding as a large saturation of diffusive species on the surface of the material.

The thicker compound layer was obtained by gas nitriding treatment. The plasma nitriding showed higher total depth of the nitrided layer.

The diffusion zone for the solid nitrided sample of AISI H13 presented different thickness measurements as shown in figure $1 \mathrm{c}$. This irregularity was also observed by Milan et al., [19].

Figure 2 shows the micrographs of AISI P20 treated by the three different nitriding methods.

The compound zones are also observed in these micrographs. And the diffusion zone is only observed for the plasma nitrided sample.

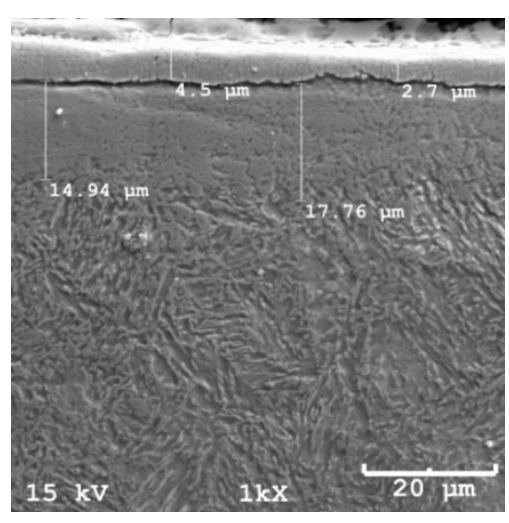

a

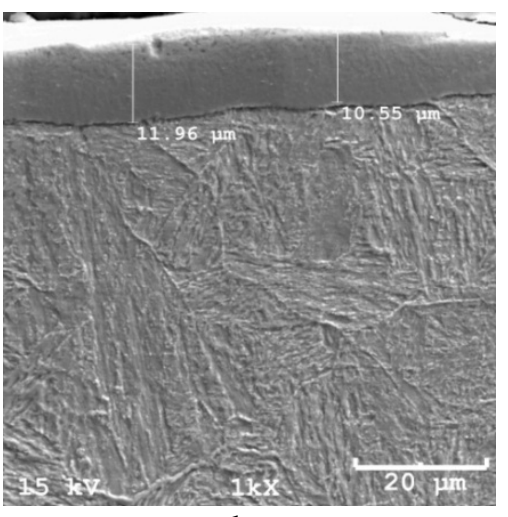

b

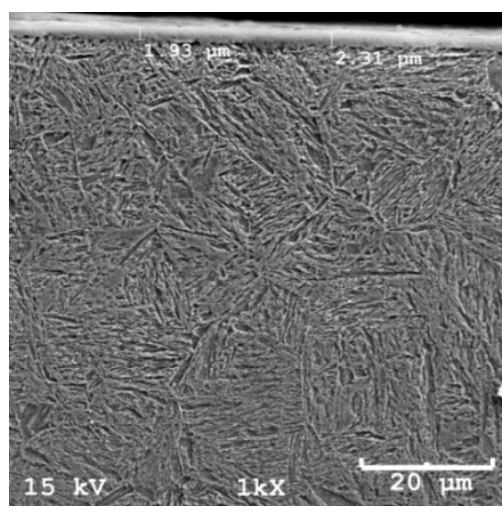

C

Figure 2: AISI P20 steel thermochemically treated a) plasma nitriding; b) gas nitriding; c) solid nitriding. 
The micrographs of N-8550 steel thermochemically treated are presented in figure 3.

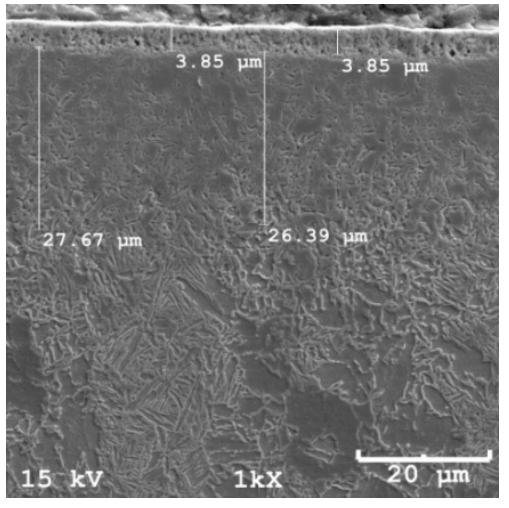

a

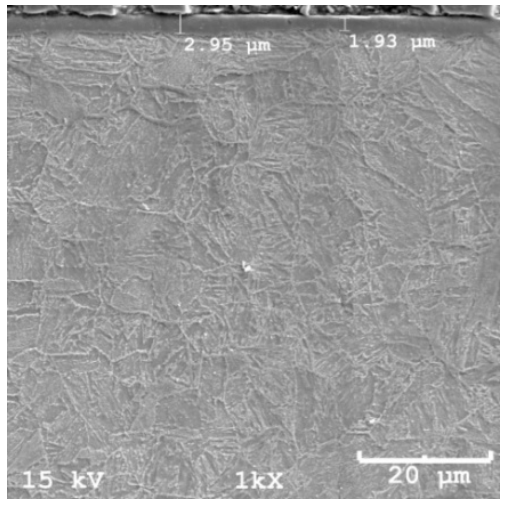

b

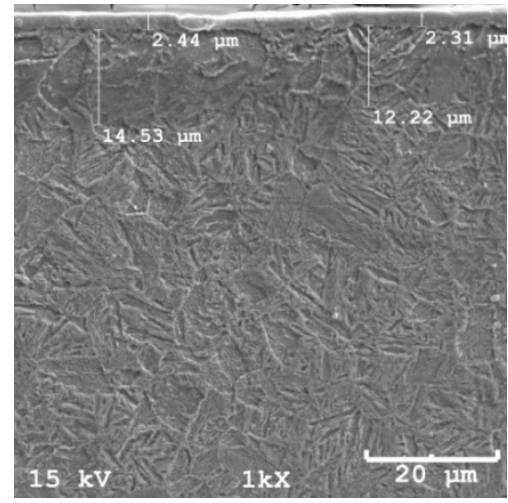

C

Figure 3: N-8550 steel thermochemically treated a) plasma nitriding; b) gas nitriding; c) solid nitriding.

Figure 4 shows the results of X-ray diffraction, obtained for the three materials submitted to plasma and gas nitriding treatments.

Figure 4 a represents the $\mathrm{X}$-ray diffraction results for the three materials submitted to plasma nitriding. As it can be seen in this figure, for the plasma nitrided AISI H13, the phases $1-\mathrm{Fe}_{4} \mathrm{~N}, 3-\mathrm{Fe}_{3} \mathrm{~N}$ and $4-\mathrm{CrN}$ are responsible for the hardening of the material. $\mathrm{Fe}_{3} \mathrm{~N}$.

The plasma nitriding treatment favored the formation of the phase $1-\mathrm{Fe}_{4} \mathrm{~N}$ in relation to phase 3 -

Figure $4 \mathrm{~b}$ shows that for $\mathrm{N}-8550$ submitted to gas nitriding the intensity of peak $1-\mathrm{Fe}_{4} \mathrm{~N}$ decreases while peak $3-\mathrm{Fe}_{3} \mathrm{~N}$ increases, compared to other materials.

The Fe peaks are more intense for AISI H13 and AISI P20 samples. The diffusion zone is characterized by having the same peaks corresponding to $\alpha$-Fe with little change of position due to expansion and saturation with nitrogen. Phases responsible for hardening in this treatment are represented by $1-\mathrm{Fe}_{4} \mathrm{~N}$ and 3 $\mathrm{Fe}_{3} \mathrm{~N}$. The $\mathrm{CrN}$ peaks in the AISI H13 were not identified by X-ray diffractometry in this treatment, maybe due to the small amount of the phase on the compound zone.
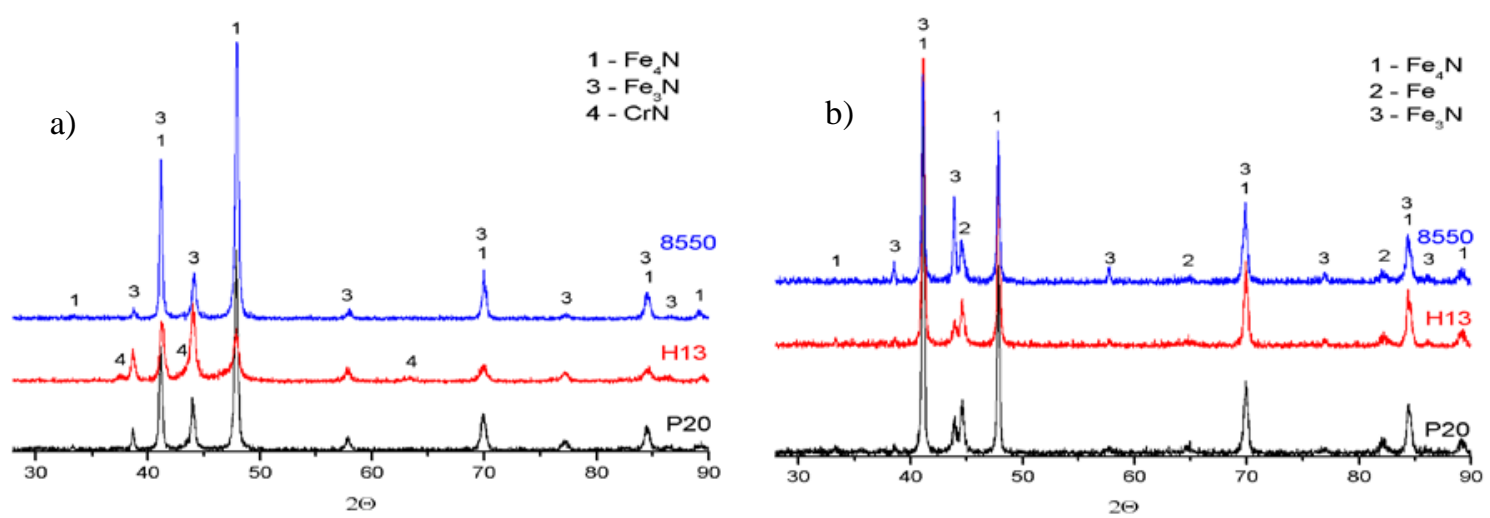

Figure 4: X-ray diffraction results of the samples submitted to a) plasma nitriding; b) gas nitriding.

The X-ray diffraction results obtained to the solid nitrided samples are represented in figure 5 . For the solid nitrided samples it is observed the formation of the phases $5-\mathrm{Fe}_{3} \mathrm{C}$ and $6-\mathrm{Fe}_{5} \mathrm{C}_{2}$. This is evidence that not only the nitrogen diffused but also the carbon diffused into the steel. These phases are formed due to the complexity of the granulated composition for solid nitriding.

The phases of interest for hardening the material are $3-\mathrm{Fe}_{3} \mathrm{~N}, 5-\mathrm{Fe}_{3} \mathrm{C}$ and $6-\mathrm{Fe}_{5} \mathrm{C}_{2}$. We can also note the presence of the phase 2 - Fe.

As previously discussed in the literature by Edenhofer, 1974 apud FRANCO JR. [18], the formation of $\mathrm{Fe}_{4} \mathrm{~N}$ phase is favored in atmospheres with low levels of nitrogen and carbon free, and as expected it is not observed in solid nitriding, where the atmosphere is not controlled. 


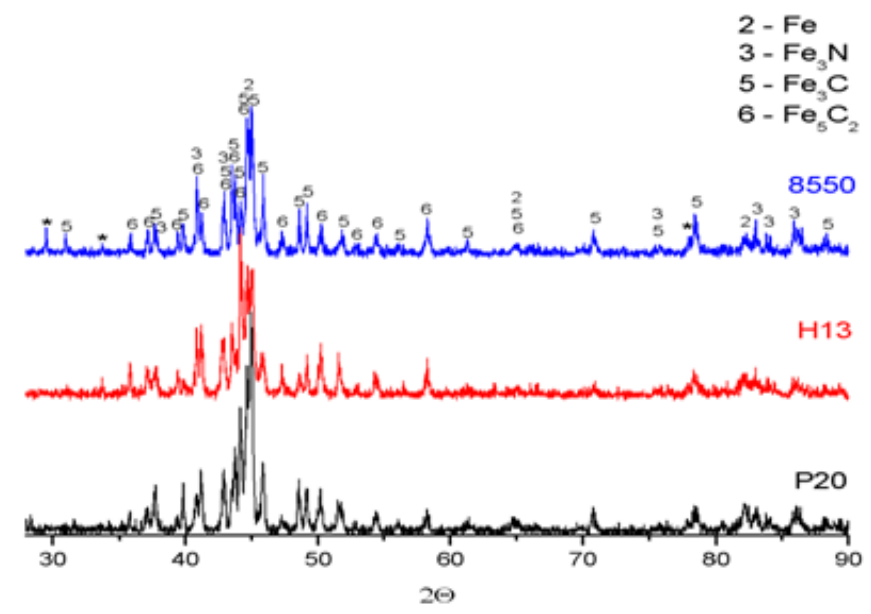

Figure 5: X-ray diffraction results of the solid nitrided samples.

Table 2 shows the bulk hardness $\left(\mathrm{HV}_{1}\right)$ of the steels before the thermochemical treatment and the microhardness $\left(\mathrm{HV}_{0.01}\right)$ obtained on the surface of the samples, these results were previously discussed by Milan et al., [19].

Table 2: Surface Microhardness results.

\begin{tabular}{c|c|c|c|c|c|c|c|c}
\hline & $\begin{array}{c}\text { NOT TREATED } \\
(\mathbf{H V 1})\end{array}$ & SD & $\begin{array}{c}\text { PLASMA } \\
\text { NITRIDED } \\
\left(\mathbf{H V}_{\mathbf{0 . 0 1}}\right)\end{array}$ & SD & $\begin{array}{c}\text { GAS } \\
\text { NITRIDED } \\
\left(\mathbf{H V}_{\mathbf{0 . 0 1}}\right)\end{array}$ & SD & $\begin{array}{c}\text { SOLID } \\
\text { NITRIDED } \\
\left(\mathbf{H V}_{\mathbf{0 . 0 1}}\right)\end{array}$ & SD \\
\hline $\begin{array}{c}\text { AISI } \\
\mathbf{H 1 3}\end{array}$ & 203 & 1.8 & 931 & 32.5 & 1040 & 75.1 & 838 & 89.7 \\
\hline $\begin{array}{c}\text { AISI } \\
\mathbf{P 2 0}\end{array}$ & 324 & 5.2 & 689 & 50.2 & 883 & 64.0 & 883 & 146.4 \\
\hline $\begin{array}{c}\mathbf{N}- \\
\mathbf{8 5 5 0}\end{array}$ & 461 & 24.3 & 689 & 19.6 & 758 & 72.2 & 797 & 87.8 \\
\hline
\end{tabular}

The results showed the effect of nitriding in the hardness of the materials. The hardness in the surface of the samples increased for all the treatments studied.

\section{CONCLUSIONS}

- $\quad$ The nitriding treatments (gas (10 h), plasma (3 h) and solid (10 h)) promoted an increasing on the surface hardness of the materials (AISI H13, AISI P20 and N-8550), due to the formation of nitriding layers (white layer and diffusion layer). Plasma nitriding has different mechanisms acting on the formation of the layers, enabling the reduction of the treatment time.

- The microhardness values obtained by the solid nitriding treatment were compatible with the hardness obtained by gas and plasma nitriding.

- $\quad$ The process called solid nitriding promoted the diffusion of nitrogen and carbon. This kind of process is known as nitro carburizing and can also improve the hardness of the material because of the formation of nitrides, carbonitrides of iron, cementite and various carbides on the surface of the metallic material. This process also promoted a greater variation of the hardness standard deviation; this can be attributed to the diffusion of nitrogen and carbon on the microstructure of the steel. 


\section{AKNOWLEDGEMENTS}

The authors wish to thank the company Bodycote-Brasimet for the gas nitriding treatment applied to the samples.

\section{BIBLIOGRAPHY}

[1] WISNIVESKY, D., ALVAREZ, F., "Nitretação iônica: tendências e potencial de uso”, Máquinas e metais, pp. 120-133, Set. 2004.

[2] FATTAH, M., MAHBOUBI, F., "Comparison of ferritic and austenitic plasma nitriding and nitrocarburizing behavior of AISI 4140 low alloy steel”, Materials and Design, v. 31, n. 8, pp. 3915-3921, 2010.

[3] KNERR, C. H., ROSE T. C., FILKOWSKI, J. H., “Gas nitriding of steels”, In: ASM Handbook, ASM International, Materials Park, Ohio, v. 4, pp. 880-922, 1991.

[4] FIGUEROA, C. A., WISNIVESKY, D., ALVAREZ, F., "Nitretação de metais a plasma: princípios, comparações com as técnicas convencionais e aplicações”, Máquinas e metais, pp. 116-123, Jan. 2007.

[5] O’BRIEN, J. M., GOODMAN, D., "Plasma (Ion) Nitriding of steels”, In: ASM Handbook. ASM International, Materials Park, Ohio, v. 4, pp. 944-954, 1991.

[6] MA, S., LI, Y., XU, K., "The composite of nitride steel of H13 and TiN coatings by plasma duplex treatment and the effect of pre-nitriding”, Surface and Coatings Technology, v. 137, pp. 116-121, 2001.

[7] OCHOA, E. A., FIGUEROA, A., ALVAREZ, F., "The influence of the ion current density on plasma nitriding process”, Surface and Coatings Technology, v. 200, pp. 2165-2169, 2005.

[8] WALKOWICZ, J., "On the mechanisms of diode plasma nitriding in N-2-H-2 mixtures under DC- pulsed substrate biasing”, Surface and Coatings Technology, v. 174-175, pp. 1211-1219, 2003.

[9] AHANGARANI, S.H., SABOUR, A. R., MAHBOUBI, F., et al., "The influence of active screen plasma nitriding parameters on corrosion behavior of a low-alloy steel", Journal of Alloys and Compounds, v. 484, n.1, pp. 222-229, 2009.

[10] FIGUEROA, C. A., WISNIVESKY, D., ALVAREZ, F., "Effect of hydrogen and oxygen on stainless steel nitriding”, Journal of Applied Physics, v. 92, n. 2, pp. 764-770, 2002.

[11] FIGUEROA, C. A., OCHOA, E., ALVAREZ, F., "Influence of the ion mean free path and the role of oxygen in nitriding processes”, Journal of Applied Physics, v. 94, n. 415, 15 AUG. 2003.

[12] GAMMER, K., STOIBER, M., WAGNER, J., et al., "Investigations on the effects of plasma-assisted pre-treatment for plasma-assisted chemical vapour deposition TiN coatings on tool steel”, Thin Solid Films, v. 461, pp. 277-281, 2004.

[13] FIGUEROA, C. A., FERLAUTO, A. S., ALVAREZ, F., "Identification of the mechanism limiting nitrogen diffusion in the metallic alloys by in situ photoemission electron spectroscopy", Journal of Applied Physics, v. 94, n. 8, pp. 5435-5437, 2003.

[14] ANICHKINA, N. L., BOGOLYUBOV, V. S., BOIKO, V. V., et al., "Comparison of methods of gas, ionic and vacuum nitriding”, Metal Science and Heat Treatment, v. 31, pp. 170-174, 1989.

[15] BOGAERTS, A., NEYTS, E., GIJBELS, R., et al., "Gas discharge plasmas and their applications”, Spectrochimica Acta, Part B. v. 57, pp. 609-658, 2002.

[16] HERNANDEZ, M., STAIA, M. H., PUCHI-CABRERA, E. S., "Evaluation of microstructure and mechanical properties of nitrided steels”, Surface and Coatings Technology, v. 202, pp. 1935-1943, 2008.

[17] CASTRO, G., FERNÁNDEZ-VICENT, A., CID, J., “ Influence of the nitriding time in the wear behavior of an AISI H13 steel during crankshaft forging process”, Wear, v. 263, pp. 1375-1385, 2007.

[18] FRANCO JR., A. R. Obtenção de revestimentos dúplex por nitretação a plasma e PVD-TiN em aços ferramenta AISI D2 e AISI H13, Tese de D. Sc., Escola Politécnica da Universidade de São Paulo, São Paulo, Brasil, 2003.

[19] MILAN, J. C. G., ALMEIDA, E. A. S., OLIVEIRA, R. D., et al., "Efeito de diferentes métodos de nitretação: sólida, gasosa e plasma sobre o comportamento ao desgaste de aços ferramentas", In: Congresso Anual da ABM, v. 64, pp. 1-8, Belo Horizonte, Jul. 2009. 